\title{
Philosophy of Sport in Poland:
}

\section{Observations}

Authors' contribution:

A) conception and design of the study

B) acquisition of data

C) analysis and interpretation of data

D) manuscript preparation

E) obtaining funding

\section{Jerzy Kosiewicz}

Josef Pilsudski University of Physical Education in Warsaw, Poland

ABSTRACT

The presented paper has a polemic and an explanatory nature. It refers to some of the inaccuracies contained in the text authored by Ivo Jirásek and Peter Hopsicker. The aforementioned authors presented the achievements of various prominent philosophers of sport from Slavic countries, including the achievements of some Polish thinkers. My observations are focused mainly on issues related to the birth and development of the philosophy of sport in Poland. I would like to thank Professor Ivo Jirásek and Professor Peter Hopsicker for addressing the topic of Polish philosophy and for their research efforts. I also would like to ask the authors to receive my comments with the good intentions with which I composed them, and hope my comments may enrich their cognitive project.

KEYWORDS philosophy of sport, physical culture, philosophy, philosophical anthropology, theology of the body

\section{Introduction}

The editorial board of the Journal of the Philosophy of Sport undertook an extremely valuable initiative to present the philosophy of sport found in non-English-speaking countries, and to portray this philosophy's properties, sources, and development. One voluminous issue of the journal has been devoted to the topic. Editors of the journal expressed plans to publish in English the most significant papers related to the topic to make them available to English-speaking readers.

In this paper I would like to address the article, which upon further analysis of its content brings - in contrast to the existing positive reputation of its authors and the substantive matter of their studies - a bit of a negative surprise. At first glance, however, this article leaves a good impression. The data on the philosophy of sport that was brought by authors seem to be both justified in the sources and well documented. The presented generalizations appear as though they were the result of in-depth reflection, were based on careful synthesis and correct interpretation, and explain and understand the characterized area of study, that is, philosophy of sport in Poland.

Unfortunately, the aforementioned text contains many misrepresentations, deficiencies, and erroneous conclusions that are discussed below. It might mislead the reader by spreading incorrect information about philosophy of sport in Poland, might be damaging for the good name of the philosophical journal, and - of no less importance - might discredit its authors.

Reading the article, one may get the impression that the authors primarily wanted its publication in a prestigious title, regardless of the possible negative cognitive consequences. What amazes me is the 
surprising methodological manner of the text: skillful presentation of inaccurate or false data as probable or truthful, and the camouflaging of incompetence in the chaos of the broader informative context that concerns the "physical education and other forms of physical activity" (not related to the topic of study). Incidentally, this informative context, not properly prepared and oversimplified, is also inaccurate with regards to factrelated content, exactly like the data regarding the philosophy of sport in Poland.

I wondered for a long time whether I should write about the content of the article in question. Finally, I decided to do so for several reasons:

1. To draw attention to the fact that inaccurate texts should not be published, and false or apparent knowledge should not be spread.

2. To remind the reader that every explanation and presentation of history - including contemporary philosophy of sport - must be consistent with the facts. With regard to factual issues, one should not create an unreal reality. Even non-fiction literature should be in accordance with confirmed, factual material.

3. To point out that statements on the history of philosophy - including contemporary philosophy of sports - will be sooner or later tested, will be subject to verification (confirmation and corroboration) and falsification (Kosiewicz 2010a, pp. 125-127).

4. To rectify disinformation and false data associated with philosophy of sport in Poland contained in the text in question.

I feel obliged - although there is no logical implication, but only an intuitive and experienced categorical imperative - to provide a brief overview of the current state of philosophy of sport in Poland.

An important part of the aforementioned Journal of the Philosophy of Sport (Volume XXXVII, Issue 2, 2010) contains a special section entitled "Sports Philosophy in Non-English-Speaking Countries". I was especially interested in the article entitled Philosophical Kinanthropology (Philosophy of Physical Culture, Philosophy of Sport) in Slavonic Countries: The Culture, The Writers, and the Current Directions, and especially its section titled Prominent Philosophers of Sport in Slavonic Countries. It has more than one page of dense text devoted to the Polish philosophers of sport ${ }^{1}$. The authors - both Ivo Jirásek (Palacky University

\footnotetext{
${ }^{1}$ Below I have provided the section of the discussed article (the passage mention at the beginning of this paper), which was the main, substantive basis for the present polemic.

"Philosophy of sport in Poland can be traced back to the turn of the $20^{\text {th }}$ century when Mariusz Zaruski wrote about the philosophical and spiritual nature of climbing and sailing. However, Marx and the Catholic Church are considered the primarily influences on modern Polish reflections of physical education and other forms of human movement. Polish scholars worked within a Marxist framework similar to the scholars in the Czech Republic. Consequently, it was not until the late 1960s when Andrzej Wohl, the first president of the International Sociological Association in 1964-1971, was recognized as the first Polish scholar to describe physical culture (and culture in general) from a historical and dialectical materialism point of view. In addition to this political influence, Poland has been and continues to be overwhelmingly Catholic - even during socialist times. The electing of Karol Wojtyla to serve as Supreme Pontiff (1978) and the first non-Italian Pope since $16^{\text {th }}$ century amplified this Christian influence into the 1980s. Further, Pope John Paul II is highly recognized by modern philosophers as inspiration for anthropological investigation, including philosophy of sport. Zbigniew Dziubinski, for example, works in sport sociology with direct connections to the philosophy of religion and Catholic anthropology.

Zbigniew Krawczyk, from the Akademia Wychowania Fizycznego (University of Physical Education) in Warsaw and a scholar from sociological traditions who championed "philosophy and sociology of physical culture," primarily developed philosophy of sport as a specific discipline in Poland. His conception of the discipline includes ontological, anthropological, methodological and axiological dimensions. His interests focus on tourism, sailing and mountaineering. Jerzy Kosiewicz, Krawczyk's former student and now professor at the University of Physical Education in Warsaw, focuses on philosophical and methodological topics of physical culture - specifically anthropological themes of body and corporeality in Christian thinking. The author uses a dynamic theory of human beings that is composed from three ontical levels: social (relational), mental (ideal) and physical (material - bodily). Most recently, Kosiewicz writes about the ontological and epistemological nature of leisure, the philosophy of physical recreation, boxing as a manifestation of movement toward absolute abstraction, and aggression in sports.

Two additional scholars from AWF Krakow contribute to the literature. Maria Zowislo uses a combination of philosophical paradigms, mythology and religion in her inquiries. This methodology targets seven basic topics: the playground of the world, culture and education, exercises, nature and culture, play and game, ethos and mythos, and corporeality. The
} 
of Olomouc) and Peter Hopsicker (Pennsylvania State University, Altoona, PA) - were not as diligent as one would expect with regards to the topic.

\section{Zaruski and philosophy}

The article says, "The philosophy of sport can be traced back to the turn of the $20^{\text {th }}$ century when Mariusz Zaruski wrote about the philosophical and spiritual nature of climbing and sailing” (Jirásek \& Hopsicker 2010, pp. 258-259). The claim that the origins of the philosophy of sport in Poland date back to the $20^{\text {th }}$ century to Mariusz Zaruskiego is a mistake, mainly because this Polish traveler was not a philosopher. Also, he cannot be considered as the progenitor of philosophy of sport in Poland. Zaruski was a general, Tatra Mountains enthusiast, and devotee of the ocean, as well as a prose writer who described his climbing and sailing experience in several factual books. In these books, one can trace - and it does not come easily - some pseudo-philosophical (rather accidental and colloquial) and very expressive, comparisons. Similar vague and general statements (though with much higher level of literary quality) are in fact frequently seen in narrative and poetic texts from the late $19^{\text {th }}$ century and early $20^{\text {th }}$ century, in which authors often rave about the aesthetics of nature.

The above statements about Zaruski can be confirmed by the quotes from his works - cited in my texts about him (Kosiewicz 2005, pp. 7-12, Kosiewicz 2008, pp. 143-151). Some of them are as follows: “The eternal Tatras, you have been (...) looking with pity over the human swarm (...) you have seen around the whole wide world” (Zaruski 1958, pp. 16-17); "The Mountain Spirit hovers over the land of Eagle” (ibid., p. 264); "One is the earth, one sun and one in Poland Tatra shrine" (ibid., p. 264); and "Despite the apparent deadness of walls, crags and gullies, this world lives its own individual life” (Zaruski 1958, p. 65). To consider Zaruski on this basis as one of the "prominent philosophers of sport in Slavonic countries" sounds like a joke or involuntary quid pro quo.

As a side note, I would like to add that I became interested in Zaruski's works about nature not because they are attractive in terms of their literary or philosophical values, but only for the reason that the author was a famous enthusiast of the Polish Tatras and the Polish sea; he was a highly qualified tourist ${ }^{2}$.

mythological, metaphorical and symbolical character of language as applied to sport is connected with all these topics from ancient Greek to modern philosophical thought.

Jozef Lipiec's line of inquiry focuses on Olympism and kalokagathia in sport and physical culture. Using these paradigms, Lipiec explores two conceptions of achievement: rivalization and perfectionism. Lipiec understands rivalization to be the mortification of a weaker person - the answering of the question, "Which one is better?" From this perspective, sporting contests are not encounters with limitations, but "fights" between human beings. Sportspersons do not wish to overcome certain boundaries, but instead need to evaluate himself/herself by overcoming living human beings - the rival. Perfectionism, on the other hand, does not need a rival. The competitor only wishes to overcome him/herself, to become better, or to reach the absolute boundaries of human possibilities. Perfectionism answers the question, "Who is the best?" Simply, perfection is a competition with a value; rivalization is a competition with an individual who is to be abased by defeat.

Finally, Wojciech J. Cynarski from the University of Rzeszow has published over 300 works on the humanistic ethos and humanistic values of martial arts. In an era of brutalization and commercialization, Cynarski attempts to establish a theoretically holistic (but interdisciplinary) construction on the humanistic and cultural aspects of sport. He utilizes philosophical sources found in Far Eastern discourses as well as sociology of religion, cultural anthropology, and theories of physical culture. Cynarski seeks to bridge the gap between technical observation (the art of the fight) and traditions of chivalry as a method of personal, holistic development”.

${ }^{2}$ Commentary on the common sense of Zaruski's statements about nature, for which I applied the method of philosophical exegesis, read as follows: "The Heraclitean order, founded on a rational cosmic power, a purposeful causative factor distinguished from human reason, strengthened the idea of a Pythagorean harmony of cosmological character. Thus it widened the philosophical base of the reflection on the properties of nature. It implicitly referred to the Heraclitean conception of a transcendent indefinite causative force influencing all nature. It referred also to Pythagorean dualism, which constituted the foundations of the harmony of the material world. It assumed that numbers restricted, shaped and regulated the functions of nature in a harmonious way. Concluding his wide experience of sea travel, Zaruski proclaimed that "Here, on this small scrap of a small globe we live on, the unmatched Pythagorean harmony of spheres is fully expressed“ (ibid., p. 65). He perceived manifestations of holistic, cosmic harmony 


\section{Karl Marx, Marxism, and philosophy of sport}

In the aforementioned text on Prominent Philosophers of Sport in Slavonic Countries, we read that "However, Marx and the Catholic Church are considered the primary influences on modern Polish reflections of physical education and other forms of human movement” (Jirásek \& Hopsicker 2010, p. 259). The information contained in this sentence and in later paragraphs of the article awoke significant concern.

First, I am not sure what the authors in this passage refer to: whether the "reflection on physical education and other forms of human physical activity," or philosophy of sport? The subsection's title suggests that the text refers to prominent philosophers of sport. However, theorists of physical education, theorists of physical culture, theorists of sport (for example, the theory of sports training and tactics experts), theorists of tourism and recreation, biomechanics or physiology of sports-related efforts specialists, as well as sociologists, psychologists, educators and historians, are not philosophers of sport. That vague and sloppy definition leads to confusion. It should be text on philosophy of sport, and it is not.

Furthermore, the authors mislead the reader, claiming, "Marx and the Catholic Church are considered the primary influences on modern Polish reflections of physical education.” They aren't influences (whether or not that's a good thing or not.) Marx didn't in any way directly impact physical education, as he didn’t in any way deal with these sorts of issues.

The analyzed fragment shows that the authors do not distinguish between the concept of Karl Marx's thought and the concept of Marxism. For them, the views of Marx himself and Marxist views are identical. Meanwhile, the thought and work of Marx himself, his philosophy, and the related legacy, are called Marxian. On the other hand, the thoughts and achievements of supporters and critical followers of the famous German economist, sociologist, and philosopher are called Marxism.

Sure enough, Marxists had in fact a small impact on the theory of physical education. Andrzej Wohl, for instance, was undoubtedly a Marxist ideologist - it definitely influenced the shape of his sociology of sport. But only his. In fact, he didn’t find followers in Poland. Polish sociology - especially after 1956 - had a pro-Western orientation and was blooming. The science was highly regarded in the West, and Polish sociologists often held the position of president, vice president, and board member of the International Sociology Association (ISA), an association affiliated with UNESCO.

It is worth mentioning that the sociology of sport in Poland - with the exception of the principled views of Wohl - wasn't pro-Marxist. That is why Wohl had no supporters or followers, and remained in constant ideological conflict with, among others, Barbara Krawczyk and Zbigniew Krawczyk.

Neither Marx's views nor the Marxists views had an impact on the philosophy of sport in Poland. Philosophy of sport was shaped and is developing in Poland today - contrary to the views of Jirásek and Hopsicker - regardless of both Marx and Marxism.

The authors of the discussed text reported that Andrzej Wohl was the president of the International

everywhere. He was experiencing it during his travels, being conscious that it concerns both the "small scrap of the small globe“ as well as the "black space sprinkled with millions of worlds” (Kosiewicz 2005, p. 11).

It is also worth mentioning that Zaruski was in the Krakow-Zakopane artistic bohemia circle of the late $19^{\text {th }}$ century and early $20^{\text {th }}$ century until the outbreak of World War II. The intellectual and artistic leader of this group, Stanislaw Ignacy Witkiewicz (Witkacy) was a great dramatist and writer, a recognized portrait painter, and a distinguished - a prolific and inventive - Polish philosopher of his time. He wasn't connected with the views of the Lviv-Warsaw School, which was close in its views to the British analytical philosophy. Zaruski belonged to bohemian group and played an important role in it. He was an extremely valued person because of his feature of being sociable.

Nota bene, he won a competition for the favor of the most prominent (after Helena Modrzejewska) and beautiful Polish actress Irena Solska (then married). He won with a much younger Witkacy, who was utterly in love with Solska. Witkacy, deeply touched and with heart failure, described the whole situation in detail (not being able to break free from compulsive neurotic behaviors) in a roman à clef, the novel called 662 Upadki Bunga [622 Falls of Bung].

In the bohemian circle, people were having love affairs, participated in scandals, use drugs and alcohol, and conducted many patriotic and philosophical disputes. Zaruski avoided these disputes because - and he didn't hide it - he felt, in terms of philosophy, like a dilettante. 
Sociology Association (ISA). That's a mistake, because he wasn't even a member of this organization. He also didn't have sociology as his educational background. He was only, in this respect, self-taught - with a doctorate, habilitation, and professorship in physical education. He founded and was president of the International Sociology of Sport Association (ISSA). He also founded and was for many years editor-in-chief of International Review of Sport Sociology. On the international arena, where he was an editor, president and board member of ISSA, Andrzej Wohl didn’t exhibit his radical ideological views.

Andrzej Wohl also had a Master's degree in philosophy, though his studies had extramural character: the degree took him only one year, and was quite superficial. Probably for this reason, Wohl didn't tie his scientific career to philosophy. Despite this, with his habilitation thesis entitled The Word and the Movement, he situated himself on the border between epistemology, philosophy of man, and physical activity. He was granted - mainly on the basis of the work thereof - a postdoctoral degree in physical education sciences. This is his only philosophical thesis. The dissertation on the topic of how the movement of the body affects the human cognition was translated into Japanese, Danish, and German. Nowhere in this monograph can either Marxian or Marxist prerequisites be found ${ }^{3}$. Therefore, it should not be associated with these concepts.

Jirásek and Hopsicker also indicate in this paragraph, "Polish scholars worked within a Marxist framework similar to the scholars in the Czech Republic” (Jirásek \& Hopsicker 2010, p. 259). The authors of this statement have erred. There was no similarity - contrary to what the authors seem to believe - between Czechoslovakia and Poland in the use of Marxist principles in science. Among the countries of Central Europe located within the ideological and political influence of the Soviet Union, Poland enjoyed considerable intellectual freedom of expression in the humanities and social sciences. On the other hand, among all the Central European countries, Czechoslovakia was the most politically indoctrinated country (particularly by communist and socialist ideas). This is particularly true with regards to the humanities and social sciences, as well as for physical education. The evidence can be found among the works of J. Merghaut and P. Joahimstaler (Kosiewicz 2010b, pp. 14-19). Czechoslovak scientists were showing even more ideological activity in this area then their allies, the Soviet "scholars."

By the way, the authors of the text, when characterizing the country during the domination of Marxism, use its incorrect name, that is, the name of the Czech Republic. Long after the social change initiated by Poland in 1989 in Central Europe (which also included Eastern Europe), and still in the 1990s, the state's official name was Czechoslovakia. The division of this country for the Czech Republic and Slovakia happened on 1 January 1993. For a long time Vaclav Havel, amongst others, was opposed to this division.

\section{Catholic Church towards the philosophy of sport}

\section{Catholic Church and physical education}

Referring to the citation presented at the beginning of the previous section, I would like to note that the Catholic Church had and has no significant impact ("primarily influences") on the prerequisites and the shape of physical education and sport in contemporary Poland. For example, the Salesian Sport Organization reproduces patterns of the Olympics for children and young people that are called Spartakiada (Spartakiad), which were developed by school systems in the Soviet Union and Poland long before the aforementioned social changes in Central and Eastern Europe. The activity of the Catholic Church in physical education, school sport, and sport for all, is the "margin of the margin." In another words, it is highly marginal

\footnotetext{
${ }^{3}$ I reviewed a book by A. Wohl entitled The Word and Movement upon the request of the International Review of Sport Sociology (Kosiewicz 1983, pp. 101-104). This book was previously published in the form of four major articles in Kultura Fizyczna, numbers 10, 11, and 12 from 1961 and one in 1962, under the title The role of the locomotor system in the development of human knowledge. This title emphasizes the substantive content more accurately then the title of the monograph of his habilitation work.

By the way, the aforementioned International Review of Sport Sociology is now called International Review for the Sociology Sport.
} 
phenomenon in terms of the size of the organizations and the number of children and young people associated with them, in comparison to government institutions, nongovernmental organizations, and the general population of children and youth in Poland. The Church's activities, in this respect, represent only one of many complementary and supplementary offers for physical education - although as with other offers, a beneficial one.

That is all with regards to the practice in physical education and extracurricular sports in Poland. The theoretical foundation of physical education and sports activities in the Polish education system isn't at all penetrated by Catholic concepts. While there are classes on religion or ethics (depending on choice) in Polish schools, there are no, for example, Catholic physical education classes, as schools and the curricula used in schools are secular in nature and must be approved by the appropriate Polish ministry (government department).

About 10 years ago I was Konrad Zielinski's thesis advisor. His doctorial dissertation was entitled Koncepcja czlowieka w pogladach polskich teoretyków wychowania fizycznego [The concept of man in the views of Polish theoreticians of physical education], which after successful defense was published under the title Człowiek $i$ wychowanie fizyczne [Man and physical education] (Zielinski 2004).

In this thesis and in the book, there is a chapter devoted to the personalistic theory of physical education that refers to Pope John Paul II's theology of the body (Zielinski 2004, pp. 171-232). I managed to convince my doctoral student to include such a chapter because earlier I'd published several articles and four monographs devoted to Christian conceptions of the body: Czelowiek $i$ jego tieło $w$ ranniechristianskoj fitosofii i doktrinie cerkwi [Man and his body in the thought of early Christian philosophy and in Orthodox Church doctrine] (1992); Bóg, cielesność i przemoc [God, carnality and violence] (1997); Bóg, cielesność $i$ mitość [God, carnality and love] (1998); and Myśl wczesnochrześsijańska i katolicka wobec ciała [Early Christian and Catholic thought concerning the body] (1998) ${ }^{4}$. In the two latter books, much attention was devoted to statements made by John Paul II on theology and philosophy of man, in particular to those thoughts related to human carnality. This part of John Paul II's thought was defined by the author as the adequate anthropology, the anthropology of the gift, and theology of the body.Konrad Zielinski, in the aforementioned thesis on physical education, refers to this theology, i.e., to my studies on this topic and suggested sources. Although in his theology the Pope presented an affirmative attitude to the human body, he didn’t consider topics with regards to physical education or sport. Also, no "inspiration /.../ for philosophy of sport” (Jirásek \& Hopsicker 2010, p. 259) seemed to appear within this theology.

In the discussed text, the conclusion regarding the inspirational role of John Paul II's theology has no -either theoretical or applied - support in the text.

\section{John Paul II towards anthropological investigation and sport}

The authors of the article in question stated, "Pope John Paul II is highly recognized by modern philosophers as an inspiration for anthropological investigation, including philosophy of sport“ (ibid.). The cited sentence is misleading. Karol Wojtyła, and later Pope John Paul II, didn’t exert influence and didn’t inspire anthropological studies of his contemporary philosophers, whether Catholic philosophers in Poland or philosophers from abroad. This notable Pole - who played a prominent role in the Vatican - was not a very distinguished philosopher (though a moderately talented poet and playwright). He was well known in Poland mainly as a representative of the Lublin School connected with the Catholic philosophy. While abroad mainly in the Vatican - he was known as a modern, dynamic, and gifted theologian. His habilitation monograph entitled Osoba i czyn [The acting person] (1968) - a philosophical treatise within the Catholic frame of thought - stresses that human intellectual, social and physical activity, that is, how a person acts,

\footnotetext{
${ }^{4}$ Due to the content mentioned in the main textbook, I was awarded with the entry "Kosiewicz Jerzy" in the prestigious 10-volume encyclopedia "Religion" released by Państwowe Wydawnictwo Naukowe (Gadacz, Milerski 2003, vol. 6, p. 55).
} 
has significant influence on the development of an individual as a person (in the ambiguous, Catholic meaning) and on the personality of each human. Unfortunately, this thesis - which had been expressed before in the Hegelian Phenomenology of Spirit, and especially in the famous theory of master and slave (Hegel 1963, pp. 216-228) - on the grounds of non-confessional, independent and secular philosophy, doesn't sound very enlightening.

Karol Wojtyła's philosophy of man didn't find a stable place in Catholic thought, but John Paul II's theology of the body (adequate anthropology, anthropology of the gift) to some extent did. This theology was at that time (in the late 1970s and the 1980s) progressive and modern compared to the petrified anthropological assumptions of the Catholic Church. The interest in his anthropology increased with the pontificate of John Paul II ${ }^{5}$.

\begin{abstract}
${ }^{5}$ I am mentioning this extended discussion to show that appreciation for the body, sensuality, and human sexuality included in the theology of the body (adequate anthropology and anthropology of the gift), quite unusual and extensive for the Catholic Church, does not contain any explicit suggestions related to the theory and practice of physical education and sport, nor it does contain the inspiration for philosophy of sport.

Pope John Paul II believes that from the biblical revelation, according to which God created man as "male and female he created them," from the mythical fact of the appearance of two sexes, stems significant ethical implications. Because, among others things, this creative act established the necessary ontological, physical, and sexual conditions for the existence of the relationship, the communion of bodies connected by love in its marital, parental, and procreative meaning. Thus, from the first biblical description of the creation of man (as well from the second one) stems the "nuptial meaning of the body," the foundation of the original (protohistoric) and historical (phylogenetic and ontogenetic) human happiness. This meaning, claims John Paul II, "will always be within, as the deepest layer, which wants to be unveiled in its simplicity and purity and wants to display its true nature as a sign of 'divine image.' This is also a path that leads from the mystery of creation, to the redemption of the body" (John Paul II 1981, p. 59).

Also, the category of "original innocence," important for the theology of the body, contains the ethical message, because connected with "original innocence" is the mystery of human existence in protohistoric time, before the knowledge of good and evil, and thus before the breaking of the covenant with God, prior to sin. John Paul II believed that to discover this secret is a prerequisite for the enhancement of bodily awareness and the understanding of the nuptial meaning of the body. The original innocence indicates that the nuptial meaning of the body is conditioned ethically and therefore in a creative, inspired and constitutive way affects the future of the human ethos. It is an indispensable foundation for the determination and full understanding of who man is and who man should be, thus how the man should (based on what values) shape his actions.
\end{abstract}

At the core of the appearance, the awakening of the needs of the nuptial meaning of the body, is loneliness, also described as isolation. The isolation causes us - says John Paul II - to suffer from the lack of a close person, the lack of an object of unfulfilled erotic love, the lack of marital love, because of the unfulfilled need for procreation. The isolation causes us to look for unity with someone we can trust, someone we can love and by whom we can be loved; that we strive for contact with the opposite sex; that we satisfy those ethically conditioned needs through the body. The fulfillment of this need is the realization of the soteriological task posed to man by God. Thus, the original innocence, the nuptial meaning of the body, and loneliness are mutually complementary categories, which positively valuate the body from the perspective of salvation.

John Paul II, pointing to the theology of the body contained in the Bible, quotes the following passage from the Letter to the Ephesians (5:21-31 Revised Standard Version) on Christian marriage: "Be subject to one another out of reverence for Christ. Wives, be subject to your husbands as to the Lord. For the husband is the head of the wife as Christ is the head of the church, his body, and is himself its Savior. As the church is subject to Christ, so let wives also be subject in everything to their husbands. Husbands, love your wives, as Christ loved the church and gave himself up for her, that he might sanctify her, having cleansed her by the washing of water with the word, in splendor, without spot of wrinkle or any such thing, that she might be holy and without blemish. Even so, husbands should love their wives as their own bodies. He who loves his wife loves himself. For no man ever hates his own flesh, nourishes and cherishes it, as Christ does the church, because we are members of his body."

John Paul II states that these words of a paraenetical tone (having the nature of moral teaching) are of key importance for the theology of the body because they represent the culmination of the synthetic speech of Christ, in which he refers to "the beginning" (Mt 19:4; Mt 10:6); to "the heart," that is, to human lust, in the Sermon on the Mount (Mt 5:27-28); and to the future resurrection (Mt 22:30; Mark 12:25; Luke 20:35). The interpretation of these words sets the theological perspective of "the redemption of the body" (Romans 8:23), not just by referring to the "historical" and thus always "modern" human, to his lust (to his "heart"), but also by opening, on the one hand, the perspective of "the beginning," or original innocence and justice, and on the other hand, the eschatological perspective of the resurrection of bodies that "neither marry nor are given in marriage” (Luke 20:35) (John Paul II 1986, p. 38). 
Theology is usually - within Catholicism - conservative, reserved for proposals for changes that come from ideas contained within the Catholic philosophy, and restrained towards new anthropological approaches. Theology is simply resistant to change and modification. It incorporates them with caution, thus

In the Sermon on the Mount addressed to the Pharisees, Jesus proclaims: "You have heard that it was said, 'You shall not commit adultery.' But I say to you that every one who looks at a woman lustfully has already committed adultery with her in his heart” (Mt 5:27-28). John Paul II shows that Christ's words have clear anthropological content, and affect these eternal meanings from which the 'adequate' anthropology is built. At the same time, because of its ethical content, these words demand that man shall complete his full picture. The man who is "the body," who through his body and sex refers to a woman (also stressed by the phrase "shall not commit adultery"), shall, in the light of the words of the Christ, find himself inside, in his "heart." The "heart" is this dimension of humanity, which directly connects with the sense of meaning of human body and the sense of order. This refers also to the aforementioned meaning, called in earlier studies "nuptial," as well as the one that was called "parental” (John Paul II 1987, p. 23).

John Paul II highlights the fact that holy sacrament also affirms the theology of the body. With the sacrament of marriage God gave to man, He endows him with love, and enshrines the sacred aspect of bodily contact in marriage, erotic love, and procreation. Through the sacrament of baptism - the washing of the head "accompanied by the word" the body is redeemed, receives its "primary purification" and its introduction to the Church. Baptism gives a man, and especially his body, the possibility of the resurrection, the eschatological perspective (John Paul II 1986, p. 355).

This type of perspective has its origins in a conversation Jesus had with the Sadducees, "who say that there is no resurrection" (Mt 22:23) (p. 254). Christ had a different opinion and ruled, which was passed in the three versions of the Synoptic Gospels by Mark, Matthew, and Luke that differ in detail, that: "The sons of this age marry and are given in marriage; but those who are accounted worthy to attain to the age and to resurrection from the dead neither marry nor are given in marriage” (Lk 20:34-35). The resurrection is like the antithesis of loneliness, nudity, sexuality, erotic love, the institution of marriage, and procreation. The resurrection assumed - according to John Paul II - the need for death and the destruction of the body, the rejection of the mundane world, to rebirth in the future world, constituting a new homeland of man. It means "not only the recovery of the body and recreation of the human life through the integral unity of body, soul; it means the brand new state" (John Paul II 1986, p. 262). It also means "the meaning of being as a body man and woman would be constituted anew, in the future world with the resurrection of the body" (John Paul II, 1986).

The category of resurrection, or "the truth of resurrection," has in the theology of the body, or "theological anthropology," a crucial importance in the sense that the whole theology be seen as "anthropology of the resurrection." However, anthropology of resurrection it is only a part of, not a synonym for, this theology. The truth of the resurrection clearly proves - according to John Paul II - that eschatological anthropology, that is, the state of perfection and happiness of man, shall not be understood in a platonic way, that is, the liberation of soul, detached from the body soul. This state needs to be understood as the state when man is finally and fully "integrated" by such a union of soul with the body, which indicated the fullness of that perfect union, treated as a fact absolutely definitive (John Paul II 1986, pp. 263-264).

John Paul II clearly stands apart from the Orphic, Platonic, and Gnostic tradition; from this Hellenistic tradition, which demands the negative attitude towards the body and its ascetic treatment. He indicates that for the Catholic and Christian the primary source of anthropology and faith shall be found in the Bible.

John Paul II also points out that in this eschatological dimension the perfect union between spirituality and corporality in human is restored. In this "worldly life the control of spirit over the body - and the concomitant subordination of the body to spirit - may become, as a result of persistent work, the expression of spiritually mature personality. However, this penetration of the body by the spiritual powers does not eliminate the possibility of their mutual opposition" (John Paul II 1986, p. 265). In the eschatological dimension human regains full corporal and spiritual harmony. It's not the original harmony - the harmony of "the beginning" - because the disruption of harmony between man and nature, between man and God, would never appear again, because it is final and absolute harmony, which is - in the Hegelian sense - a synthesis of the "initial" (paradise) state and worldly state, it is body-spirit synthesis and harmony that strives for salvation. This harmony means "excellent participation of all corporal aspects of man in the spiritual aspect of the man. It also means a perfect realization of the personal aspect of human,” (John Paul II 1986) the highest-level deification of nature and union with God.

John Paul II, stressing the sacred pedigree of the body, sex and erotic love, and their importance in the soteriological process, indicates that they are a source of regulative norm, the foundation for the implementation of standards of the ethics of nobility. A hermeneutic interpretation of the scriptural message presented by the author is an analysis consistent with Christian orthodoxy that represents continuity and development of the conception of the body according to Genesis, Jesus, and Paul (Paul of Tarsus), and the enhanced tendency to re-evaluate the meaning of the body that is present in the legacy of Aurelius Augustine and Thomas Aquinas.

The theology of the body of John Paul II is a consequence of a biblical trend, initiated in early Christianity, which defies the Platonic and Gnostic (Apollonian, Orphic, Pythagorean, and Platonic) negation of the body, and is an important and consistent attempt to overcome the Hellenistic tradition, which weighed heavily in a negative way on Christian anthropology (Kosiewicz 1998, pp. 118-123). 
reducing possible risks that new ideas can bring. But it was not philosophy that brought a new trend in the widely understood Catholic anthropology, but surprisingly, it was theology. Ultimately, however, John Paul II's proposed concepts of theology of the body didn't resonate on a large scale throughout the Catholic Church, either in theology or in Catholic philosophy. Both his philosophical (including the difficult-to-read arguments, especially in The acting person) and his theological approach received neither significant nor important application. His thoughts are now only one of many anthropological trends within the Church. This is neither a representative nor an official trend. Catholic thought - including the philosophy of man - is still not interested in over-exposing the physical needs of man or the topic of human sexuality.

The philosophical and theological views of John Paul II had no special impact in Poland on the philosophy of man (especially the secular one) or, in particular, on philosophy of sport. As a philosopher who deals with the concepts of the body in Christian thought, I had to take into account not only Jewish, ancient Greek (pre-philosophical, both of a religious and philosophical nature), early Christian, medieval, modern and contemporary, Orthodox Church, Protestant and Catholic conceptions of man (within theology and philosophy), but also the publications of this great Pole. Thus I was also interested in John Paul II's statements.

On this basis, I concluded that the ideas contained in John Paul II's theology of the body had another ancestor, however. It was the Catholic theologian Cardinal Karl Rahner, who in the 1960s, in his thesis that had typical theological characteristics, introduced a reflection on the theological dimension of physicality and human sexuality (Rahner 1979, Kosiewicz 1998). Incidentally, John Paul II unfortunately never indicated - at least in the publications I am aware of - the identity of his predecessor and source of his inspiration for developing the Catholic theology of the body ${ }^{6}$.

I would like to add that the appreciation of the human body and human sexuality appeared much earlier in the philosophy of Orthodox Christianity than in Roman Catholicism. This applies in particular to the trend that occurred in the late $19^{\text {th }}$ century and early $20^{\text {th }}$ century in the anthropological thought of the Russian Orthodox Church. This trend was associated with the extensive, internally diverse movement referred to as "new religious consciousness." The movement was formed by philosophers of such magnitude as W. W. Rozanov, D. S. Merezhkovsky, W. S Solovyov, and N. A. Berdyaev. They stamped their impact not only on philosophy but also on many other areas of the humanities, such as the understanding of literature and the arts as well as social issues (it also concerns traditional religiosity that refers to so-called "historic Christianity"). Their views created - as opposed to the official and orthodox interpretation of the Church - a significant breakthrough in the valorization of human carnality, sensuality, passion, sex, and the natural needs of sexual love. These ideas created a message for the new anthropological option, which showed sensuality and passion founded on its biological substrate, and that introduced the essence of erotic love in the context (not only in Rozanov's works) of the mystical assumption of the Orthodox Church. (Kosiewicz 1998, pp. 194, 205).

When in many cases the novelty of the Russian Orthodox Church relies mainly on relating to and incorporating many concepts from Western philosophy ${ }^{7}$, the anthropology, especially the dissident

\footnotetext{
${ }^{6}$ John Paul II treated issues contained in the seventh thesis of Rahner, and the remainder of the theses that concern the theological dimension of corporality, in a manner consistent with the recommendations of the German thinker, and considered them in a biblical-theological perspective. He particularly focused his consideration on the exegesis and hermeneutics of the biblical messages, making them a foundation for the interpretation of contemporary theology, Church teaching, and Catholic philosophy now mainly expressed in the comments contained in three books on John Paul II and his theology of the body. John Paul has interpreted the assertions contained in the indicated theses in a specific and different manner. The differentiations and turning points contain the presented theology of the body.

John Paul II points to the so-called beginning of man, to the compliance his nature with the image and God's intent, to the need for erotic love - platonic only in the sense that erotic love has to be satisfied, because it is the condition of procreation, but satisfied only in marriage. This kind of love is also a testimony of the responsibility and love for God (Kosiewicz 1998, pp. 134-135).

7 This comment applies to the second trend that was characteristic of the Russian Orthodox Church, derived from research achievements of religious academies in Russia in the second half of the $19^{\text {th }}$ century and early $20^{\text {th }}$ century,
} 
movement from the circle of "new religious consciousness," bore new solutions on the ontology of the body, sex and erotic love, which in every respect were novel in relation to Protestantism and decades ahead of the theology of the body created by John Paul II (Kosiewicz, 1998, pp. 194-195) ${ }^{8}$.

\section{Prominent philosophers of sport and Zbigniew Dziubiński}

While characterizing the anthropological views of John Paul II, the authors of article in question also refer to the achievements of Zbigniew Dziubiński. They write: "Zbigniew Dziubinski, for example, works in sociology with direct connections to the philosophy of religion and Catholic anthropology” (Jirásek \& Hopsicker 2010, p. 259). This reference and the following statement are not very accurate for two reasons:

a) from a formal point of view, these two persons are quite different in terms of influence, activity, and social reception;

b) from the point of view of substance, because Dziubiński is neither a theologian nor a philosopher of religion. He has aspirations with regards to the sociology of physical culture and sports. Karol Wojtyła - Pope John Paul II - shared none of these. This is still not enough to place both thinkers - as did the authors of the discussed article - among the prominent philosophers of sport.

It is worth noting that Zbigniew Dziubiński was attached to a Catholic community for more than 30 years. Within this community he holds an important social function. Religious topics frequently appear in his

which presented a high level of teaching and science. Although the trend was imbued with considerations that had confessional and para-confessional assumptions, they also had scientific, innovative, and libertine tones, referring to the latest trends in science and philosophy. Representatives of the trend - that is, such philosophers and, at the same time, theologians such as W. D. Kudryavtsev-Platonov, W. I. Niesmielov, and P. D. Jurkiewicz - emphasized the important function of the body in the cognitive, mystical, and soteriological process (Kosiewicz 1998, pp. 194, 201-205).

${ }^{8}$ The views of W. W. Rozanov are a suitable example. His surprisingly innovative ideas were audacious in comparison to Christian concepts and remained in radical conflict with the anthropology of Russian Orthodox Church. In his writings one cannot find the concept of extending of the anthropological category of the body and sex into the concept of the Orthodox community, or assigning to these categories universal properties. In fact, corporality and sexuality become concepts that indicate the possibility of communication between people and the opportunity for establishing the connection with God. On one hand, the body, senses, and sexuality prevent atomization of the individual and trigger the need for horizontal relationships. On the other hand, it causes vertical correspondence, and become a means to experience God in a bodily experience. In this sense, a true, sensual carnal act is - according to W. W. Rozanov - not just an alliance with another person, but also the mystical experience, a way of understanding the mystery of God. If the aim of the physical act is merely a sensory experience, with no contact with God, if the senses in physical intercourse reach only an approximation with another person, this phenomenon can only be called debauchery. The basis for overcoming a person's own ego towards the other person in order to experience the mystical union with God is the subject, the individual, with physical and sexual needs. Because only the subject as an individual believer, with his own, limited orientations, can sense sexual experiences, and get to know the secrets of God. That is why this anthropology, in contrast to D. S. Merezhkovsky's anthropology, has a strictly individualistic, not pro-community, overtone. The path leads from the individual to God. The body and its sex is a tool. At the same time, W. W. Rozanov emphasized, only the believer can experience the full satisfaction of the body and the true nature of sex. In this sense, the atheist is an asexual being, unable to know the true cause of sexual love's meaning, unable to penetrate and understand its own nature. The source of bodily existence of human is the creative plan of God. The sex is the result of the metaphysical plan, which gives the opportunity to experience the mystical connection. Biology is divinized, corporeality and sexuality are saturated with the divinity (in genetic, functional, salvific, and mystical terms), and erotic experience becomes a profound religious experience (Krzemień 1979, pp. 87-88).

The consequence of divinization is the negation of ontological dualism, which undermines the traditional theological assumptions of body and sex. W. W. Rozanov criticized Orthodox Church anthropology in the name of the value of the body. He considered sex - that is, gender (that he deified) - the most important determinant of anthropology, because through it, through sensuality (but not only), the mystical goal can be achieved. Though through the soul humans also come closer to God, the soul is not an overriding factor and the only source of cognition, but the second and parallel component, which coupled with corporality, creates a unified and a full organic and psycho-emotional cognitive act. However, according to W. W. Rozanov, the body does not "express" spiritual experience. The same physical sensations are simultaneously mental, erotic, and mystical experiences. In a cognitive meaning the difference disappears because the most winged, the most personal spiritual experience cannot exist separate from the body; they are identified with the bodily and sex-related reactions. Personality, a person, and humanity, and thus the essence of the human individual, is identified with the instincts and the pursuits of nature (Kosiewicz 1998, pp. 207-208). 
work, particularly in the two dissertations he did. The topic of his habilitation concerns the area of the sciences of physical culture. These two theses have the nature of sociological studies.

Dziubiński doesn't look for any connections and doesn't have any ambitions in this regard that associate him - contrary to what is mentioned in the discussed article - with the philosophy of religion. He doesn't deal with the topic in detail. Of course, as a scholar and a highly talented scientist he often refers to philosophical studies.

I really don't understand where the authors of the discussed article got the information, which is completely detached from reality, that "the Catholic Church" in Poland, "was the one of the primary influences on modern Polish reflections of physical education and other forms of human movement” (ibid.).

I also don't understand why the authors have even brought up this type of consideration that is inconsistent with the truth, and which is not associated with a task they undertaken. I would like to recall that the task was to present - as indicated in the discussed passage - "prominent philosophers of sport in Poland."

\section{Polish, Catholic-oriented philosophers of the sports}

Ivo Jirásek and Peter Hopsicker wrote about prominent philosophers of sport in Poland, presenting Karol Wojtyła (John Paul II) and Zbigniew Dziubiński. Meanwhile, neither of them - as we know - are philosophers of sport or Catholic philosophers of sport.

It is surprising that the authors failed to mention that in Poland many Christian -particularly Catholic philosophers randomly expressed their opinion about sport. Three of them significantly contributed to the philosophy of sport in Poland, and they should have been mentioned. They wrote a comprehensive book about the philosophy of sport. This applies to Zachariasz Łyko, Stanisław Kowalczyk, and Mirosław Mylik. Ivo Jirásek knows the last two, yet he didn’t mention them in the aforementioned passage. The works of all three of them are widely available, as are opinions about them in several papers.

Stanisław Kowalczyk is regarded as one of the greatest Catholic philosophers in Poland. He wrote among other things - a monograph entitled Elementy teologii i filozofii sportu [Elements of theology and philosophy of sport] (2002), which I reviewed. Zachariasz Łyko is one of the greatest Protestant philosophers in Poland. He also deals with the philosophy of sport. This is evidenced by numerous articles and chapters in books he has authored, as well as a monograph entitled Filozofia rekreacji, sportu i turystyki [The philosophy of recreation, sport and tourism] (2003) that I have commented on at length on several occasions. Mirosław Mylik, in turn, authored Podstawy filozofii sportu [The basics of philosophy of sport] (1997) (I reviewed that book as well), and many other extensive and erudite books on Catholic philosophy. It is expected that he will soon achieve - as will the two others - the status of outstanding thinker.

The works of these three great Christian philosophers ennobles sport as a form of physical activity and philosophy of sport as a subject of sophisticated research. They cause a growing interest in this topic. However, it mustn't be stated that - they or any other representatives of Catholic thought - have "primarily influences on modern Polish reflections of physical education and other forms of human movement" (Jirásek \& Hopsicker 2010, p. 259). They don't have that kind of influence because:

a) they don't deal with physical education as a theory and practice;

b) their statements about sport in general and tourism and recreation indicate that because of lack of personal contact with competitive sports and with the science of physical culture (the science of sport), these thinkers are not specialists in the aforementioned issues.

The texts authored by Łyko, Kowalczyk, and Mylik showed, on the one hand, highly qualified philosophical competence, and on the other hand, a lack of elementary knowledge about the realities of sport and non-philosophical theoretical reflection associated with sport. A variety of generalizations, valuations, provided explanations, and attempts of understanding all contain surprisingly simplistic, even naive, observations. Although there is an interest in the works of the indicated authors, they didn't play a significant role in the development of philosophy of sport in Poland. We support their publications, and expect further, 
more substantive - in relation to sport - development. In the cases of Stanisław Kowalczyk and Zachariasz Łyko, such expectations are hopeless though, because the former's publication on philosophy of sport is limited due to old age (he has turned 80 years old); the latter has already passed away. We could possibly count on Miroław Mylik and other authors his age for the Christian perspective. But not many of them display - in contrast to Mylik - much interest in reflection about sports.

\section{Is Wojciech Cynarski a prominent philosopher of sport?}

Wojciech Cynarski is quite extensively presented by the authors (in the cited passage, which is in Endnote number 1). Meanwhile, in the article in question he should not be taken into consideration for formal reasons, since he is not a philosopher after all, nor does he deal with the philosophy of sport. This also applies to other people involved in the social science of sport (other than philosophy): sociologists, educators, psychologists, historians of sports and specialists from sports organizations, specialists of sports management, specialists of tourism and recreation (sport for all). The authors also did not explain why - out of the large number of professors involved in the aforementioned sciences - they chose but one person, Wojciech Cynarski.

In addition, it's worth mentioning that contrary to what the authors have suggested, he is not a sociologist of religion. Wojciech Cynarski indeed deals with issues of religion in his work, but only because martial arts, Cynarski's topic of considerations, are often founded on some religious aspect. It didn't make Cynarski a sociologist of religion, though. And furthermore, how does this relate to the philosophy of sport in Poland and its prominent representatives?

\section{Krawczyk and Kosiewicz - relationship}

The authors also mention that I (Jerzy Kosiewicz) was a student of Zbigniew Krawczyk. I don’t know what the authors intended to say by this, that is, what kind of additional information they wanted to convey. The fact is that Krawczyk has played an important role in my life. In 1981 he hired me to work at the Department of Philosophy and Sociology at the University of Physical Education in Warsaw. He supervised my doctoral dissertation (in 1984), and as the head of the university he entrusted me - after I received the title of doctor with habilitation degree in the philosophy of religion (in 1993) - with the position of head of the Department of Philosophy.

While a student I only met Zbigniew Krawczyk a few times. He did not influence my studies. I finished the University of Physical Education in Warsaw (MA in 1973), and then I obtained an MA in philosophy at the University of Łodz (1978) and an MA in cultural studies - with a specialization in theater studies - from the University of Łodz (in 1986). I also graduated from the Faculty of Philosophy and Sociology of the University of Warsaw (in 1984) with a degree in religious studies. Zbigniew Krawczyk, incidentally, as my boss, was opposed to the last degree, and actively and repeatedly argued against my decision to finish this study.

\section{Address Inadequacies}

The authors also give the wrong place of employment of Zbigniew Krawczyk. First, the authors indicated that he is an employee "of University of Physical Education in Warsaw”. Meanwhile, the official name of the university - in accordance with the statute - for 7 years has been Josef Pilsudski University of Physical Education. Secondly, Krawczyk - contrary to what the authors stated - no longer works at the university. He became a professor emeritus in 2000 (12 years ago). For the past 12 years he has also been employed as a professor at the Almamer School of Economics in Warsaw.

The authors - despite the fact that they chose such a convention for the discussed paper -were inconsistent in the giving the place of employment of others persons mentioned in the article. They didn't 
provide information about the place of employment of Andrzej Wohl. He hired and supervised Zbigniew Krawczyk and Barbara Krawczyk at the Joseph Pilsudski University of Physical Education of Warsaw.

They also didn't mention the two parallel jobs of Józef Lipiec: Jagiellonian University and the University School of Physical Education in Krakow (he resigned from the latter a few months ago).

They didn't inform the reader that for 25 years Karol Wojtyła directed the Department of Ethics at the Catholic University of Lublin - until his appointment to the chair of Saint Peter in Rome, i.e., until the beginning of his pontificate as pope in 1978. As a matter of fact, the night Karol Wojtyła was elected pope, the university authorities convened a special meeting of the university's Senate, and recommended giving Karol Wojtyła the title of professor. Until then he had held position of the head of the department of ethics as habilitated doctor.

\section{Other comments}

1. The authors of the paper took no notice of the current state of philosophy of sport in Poland. Mentioned among the active philosophers in the field are only Józef Lipiec (the authors for some reason chose to extensively discuss some aspects of his views, as compared to other philosophers mentioned in the paper), Maria Zawisło, and myself.

The authors also mentioned Zbigniew Krawczyk, although he hasn't been active in a field of philosophy of sport for 20 years. They also didn't sufficiently highlight the fact - which is important for his academic activity - that he has always primarily regarded himself as a sociologist of culture (under the influence of Antonina Kłoskowska, the greatest sociologist of culture in Poland), and a sociologist of sport. His early considerations on the philosophy of sport were founded mainly on statements from the Polish philosophical textbook. He has never attended, nor does he now attend, the international, European and British, or national conferences related to the philosophy of sport. Also, he hasn't affiliated himself with any association related to the discussed issues. He had no such need, or such ambitions. However, for decades he was an active member of the International Sociology of Sport Association (since the creation of this organization in the early 1960s), and held major functions in it. He was honorary member of the association. For decades, he was a member of the editorial board, the secretary, and later, deputy editor-in-chief of International Review for the Sociology of Sport.

2. In addition to prominent persons from the circle of Polish Christian philosophy, both Catholic and Protestant, who deal with the philosophy of sport, the authors also failed to mention contemporary philosophers of sport that have become more and more well-known:

a. Marek Kazimierczak - philosopher (Neo-Kantianism) from the Eugeniusz Piasecki University School of Physical Education in Poznan, who for several years has already primarily been dealing with philosophical foundations of tourism and recreation. Among other things, he is an editor of the six collective works devoted to the humanities and social foundations of tourism. He also organizes regular conferences related to this subject. He is a participant in the annual conference of the Polish Society of Social Sciences of Sport.

b. Tomasz Sahaj - social philosopher from the Eugeniusz Piasecki University School of Physical Education in Poznan. He focused his attention on deviation in sport, especially on the background, conditions, and forms of public perception of disorderly behavior in sport, particularly in football. He is an author (in this respect) of a comprehensive monograph (Sahaj, 2007), and an editor of two collective works on the sport. He attends regular conferences of the Polish Society of Social Sciences of Sport.

c. Tomasz Michaluk - philosopher at the University School of Physical Education in Wroclaw. He is the author of a monograph entitled Semiotyczne i pragmatyczne zagadnienia teorii sportu [Semiotic and pragmatic issues of the theory and of sport] (2011) on the topic of the possibility of the application of the philosophy of Charles Peirce to the process of explaining 
and understanding the properties, meaning, semiotics, and symbolism of contemporary sport. He attends regular conferences of the International Association for Philosophy of Sport, the European Association for the Philosophy of Sport, the International Society for the Social Sciences of Sport, and the Polish Society of Social Sciences of Sport.

d. Krzysztof Pezdek (2010) - philosopher at the University School of Physical Education in Wroclaw. In several statements he considers, among others issues, the issue of axiology of sport as well as the ethical factors of sport for persons with disabilities. He is a regular participant - like Tomasz Michaluk - in conferences of the International Association for the Philosophy of Sport, the European Association for the Philosophy of Sport, the International Society for the Social Sciences of Sport, and the Polish Society of Social Sciences of Sport.

e. Jakub Mosz - philosopher, aesthetician of Josef Pilsudski University of Physical Education of Warsaw, he is also associated with the history of art and culture. From the perspective of those areas, he talks about the various characteristics of sports. He is an author of a monograph on the topic of sports in Polish documentaries. His work has qualities of aesthetic studies, genre studies, and film studies. (Sfilmować ruch. Sport w filmie krótkometrażowym [Filming the movement: sport in the genre of short films] (2003). He regularly attends conferences of the International Society for the Social Sciences of Sport and the Polish Society of Social Sciences of Sport.

f. Alicja Przyłuska-Fisher - philosopher from the Josef Pilsudski University of Physical Education of Warsaw, mostly occupied with bioethics, medical ethics, and the ethics of sport. She co-authored (with Bohdan Misiuna) a book entitled Etyka Sportu [The ethics of sport] (1993, pp. 7-91).

g. Katarzyna Salomon-Krakowska - philosopher from University School of Physical Education in Wroclaw. Her interests concern the issues of corporeality in the cultural and philosophical context with particular emphasis on the phenomenology of the bodies of disabled people (especially in the context of the phenomenology of Merleau-Ponty). She also considers the relationships between sport and the aesthetic properties of the movement.

On that note, Ivo Jirásek met Tomasz Michaluk, Krzysztof Pezdek and Jakub Mosz, and he had the chance to get to know their works numerous times.

3. In further observations I will extend my comments to a passage in the above-citied endnote number one, and I will refer briefly to other fragments of the discussed article.

a) The fragment of the article in question, entitled Traditions of Inquiry in Sport and Physical Educations in Slavonic Countries (Jirásek \& Hopsicker 2010, pp. 255-256), which follows the section Prominent Philosophers in Slavonic Countries (ibid., pp. 256-270), can be characterized by clear, substantive clumsiness, as well as some cognitive dissonance, probably resulting from insufficient information about research in the field of sport and physical education in the Slavic countries other than the Czech Republic. It is otherwise difficult to explain where the surprising asymmetry in the presented content comes from. Only two small paragraphs - less than 22\% (!) - of the entire text is devoted to research "in Sport and Physical Education” in countries other than the Czech Republic, that is, in Poland, Slovakia, Slovenia, Serbia, and Russia. An average of less than $4.5 \%$ is allocated to each of these countries. I emphasize with undisguised amazement that $88 \%$ of the considerations are devoted to the Czechs. That might lead to the conclusion that the Czech Republic in the study of sport and physical education is - in comparison with others - almost unimaginably powerful. Moreover, the authors introduce the philosophical context in the discussed passage, which focuses exclusively on the philosophy of the Czech philosophical tradition (without reference to any of the other Slavic countries). The thoughts on the phenomenological philosophy of Jan Patocka (who, incidentally, is known only in Czech) dominate the fragment. Also mentioned are the German philosophers Edmund Husserl and Martin Heidegger, as they were Jan 
Patocka's teachers, and Eugen Fink, for Patocka was his friend. There is no explanation of what kind of impact this relationship had on the philosophy of sport. Also, the reader won't find any information about how these philosophers and their relationships are related to Polish, Russian, Slovak, Slovenian and Serbian philosophies, or any other information about these philosophies. Why? No one knows. The Czechs once made a movie entitled Nobody knows anything. Could it be possible that this title represents not only Czech film?

b) The situation created by the authors of the text is so paradoxical that it is almost humorous. It would be as if when discussing the philosophies of English-speaking countries, one only presented the philosophy of New Zealand and the achievements of several philosophers, for example, from Germany or Austria.

c) In addition, it could be proved that Bohuslav Hodan is not at all a philosopher, and has no inclination towards the philosophy of sport. By the way, he did not even participate in the conference of the International Association for the Philosophy of Sport in Olomouc in 2005, though at that time he was at the Palacky University (about 100 meters from the conference venue). He also didn't participate in meetings of the philosophy section during the Third Conference of the International Society for the Social Sciences of Sport, which took place at the same university in 2011. The authors of the article in question devoted the most space to Hodan. At the same time they mentioned Irena Martinkowa only three times (ibid., pp. 257, 262, 263), who, in contrast to Bohuslav Hodan, brought major achievements to Czech philosophy of sport.

d) The article should provide more information on distinguished philosophers of sport such as Lev Kreft from Slovenia and Vladysłav Stolyarov from Russia (the latter has achieved much in the field of methodology and aesthetics of sport).

e) I know L. P. Matveyev personally. I also know his work. His studies mainly concern the socalled general theory of physical culture. He does not conduct research in the philosophy of sport or the philosophy of physical culture. The same could be said about B. G. Akchurin and A. P. Buzov. In fact, they were probably presented in the discussed text (each author separately) based on one - and quite random - article (ibid., p. 261).

f) Neither Zofia Żukowska nor Ryszard Żukowski are Polish philosophers of sport. Also, Artur Litwiniuk can't be labeled with name "philosopher of sport." They personally never think about that. Żukowska's subject is pedagogy, and Żukowski and Litwiniuk are active in the field of theory of sport. Incidentally, they also spoke about the principle of fair play. Żukowski's texts have ideological, propagative, and moralistic overtones. It is noticeable in his publications and during the meetings of the European Movement for Fair Play (I was the keynote speaker at one of these meetings). Litwiniuk wrote on this topic only a few times, and his publication has a rather non-scientific character. To mention Litwiniuk's name in the context of the philosophy of sport is astonishingly careless - so surprising, it's incredible.

I would like to add that almost all Polish theoreticians and practitioners of sport spoke about fair play. In addition to philosophers, those who discussed the topic were sociologists, psychologists, educators, historians, political scientists, theorists of physical education, sport theorists, coaches, physical education teachers and representatives of various institutions and sports governing bodies. It doesn't mean that all these people deserve to be labeled a philosopher of sport.

In conclusion, it is worth advising the authors of the discussed text that one who speaks on issues related to sport, physical education, or physical education cannot automatically be considered a philosopher of sport - either in a formal or in a substantive sense.

It's not a good practice to take into consideration random names of those who one happens to know and create an imaginary, false reality. In science, wandering in the dark is not allowed, as it does not lead to success. 


\section{REFERENCES}

Gadacz, T., Milerski, B. (Eds.) (2003). Religia /Religon/ (Vol. 6). Warsaw: PWN.

Hegel, G.W.F. (1963). Fenomenologia ducha /Phenomenology of spirit//Vol. 1). Warsaw: PWN.

Jan Paweł II (1981). Mężczyzna i niewiasta stworzyt ich. Chrystus odwoluje się do „poczatku”. O Jana Pawła II teologii ciata /Male and female he created them: Christ refers to the "beginning." John Paul II's theology of the body/. Lublin: Wydawnictwo Katolickiego Uniwersytetu Lubelskiego.

Jan Paweł II (1983). Mężczyzna i niewiasta stworzyt ich. Chrystus odwotuje się do ,zmartwychwstania”. O Jana Pawta II teologii ciata /Male and female he created them. Christ refers to the "resurrection." John Paul II's theology of the body/. Lublin: Wydawnictwo Katolickiego Uniwersytetu Lubelskiego.

Jan Paweł II (1986). Odkupienie a sakramentalność matżeńska /Redemption and the sacramental marriage/. Vatican.

Jan Paweł II (1987). Mężczyzna i niewiasta stworzyt ich. Chrystus odwotuje się do ,serca”. O Jana Pawta II teologii ciala /Male and female he created them. Christ refers to the "heart." John Paul II's theology of the body/. Lublin: Wydawnictwo Katolickiego Uniwersytetu Lubelskiego.

Jirásek, I. Hopsicker, P.M. (2010). Philosophical Kinanthropology (Philosophy of Physical Culture, Philosophy of Sport) in Slavonic Countries: The Culture, The Writers, and the Current Directions. Journal of The Philosophy of Sport, 27(2), 258-2260.

Kosiewicz, J. (1983). The Lost Paradigm: Human Motoricity. International Review of Sport Sociology, 1(18), 101-104.

Kosiewicz, J. (1992). Czelowiek i jego tieło w ranniechristianskoj fitosofii i doktrinie cerkwi. Moscow: Diepon. INION Rasijskaja Akademia Nauk, 46258.

Kosiewicz, J. (1997). Bóg, cielesność i przemoc /God, carnality and violence/. Warsaw: Aletheia.

Kosiewicz, J. (1998). Bóg, cielesność i mitość /God, carnality and love/. Warsaw: Aletheia.

Kosiewicz, J. (1998). Karl Rahner - teologiczny wymiar cielesności i seksualności ludzkiej. In Bóg, cielesność i miłość /Karl Rahner: a theological dimension of carnality and the human sexuality. In God, carnality and love/ (pp. 126-133). Warsaw: Aletheia.

Kosiewicz, J. (1998). Myśl wczesnochrześcijańska i katolicka wobec ciała /Early Christian and Catholic thought on the body/. Agencja Wydawniczo-Poligraficzna "Witmark."

Kosiewicz, J. (2005). Tourism and sacrum. European Journal for Sport and Society, 2(1), 7-12.

Kosiewicz, J. (2008). The anthropological background of the philosophical reflection on nature and tourism. European Journal for Sport and Society, 5(2), 143-151.

Kosiewicz, J. (2010a). On Methodology and Hypothesis. In Sport and Philosophy: From Methodology to Ethics (pp. 87-140). Warsaw: Wydawnictwo BK.

Kosiewicz, J. (2010b). Social and Biological Context of Physical Culture and Sport. Physical Culture and Sport. Studies and Research, L, 5-31. DOI: 10.2478/v10141-010-0021-1.

Kowalczyk (2002). Elementy teologii i filozofii sportu /Elements of theology and philosophy of sport/. Lublin: Wydawnictwo Katolickiego Uniwersytetu Lubelskiego.

Krzemień, W. (1979). Filozofia w cieniu prawostawia /Philosophy in the shadow of the Orthodox Church/. Warsaw: KiW.

Łyko, Z. (2003). Filozofia rekreacji, sportu i turystyki /Philosophy of recreation, sports and tourism/. Warsaw: Wydawnictwo Chrześcijańskiej Akademii Teologicznej.

Michaluk, T. (2011). Semiotyczne i pragmatyczne zagadnienia teorii sportu/Semiotic and pragmatic questions of the theory of sport/. Wrocław: Wydawnictwo Akademii Wychowania Fizycznego.

Mylik, M. (1997). Podstawy filozofii sportu. Podręcznik ruchu parafiadowego /The basics of philosophy of sport: manual of the 'Parafiada' movement/. Warsaw: ATK.

Mosz, J. (2003). Sfilmować ruch. Sport w filmie krótkometrażowym /Filming the movement: sport in the genre of short films/. Warsaw: Wydawnictwo AWF.

Pezdek, K. (2010). Elementy ujęć systemowych w twórczości Henryka Bergsona /Elements of the system's approaches in the works of Henri Bergson/. Wrocław: Oficyna Wydawnicza ATUT - Wrocławskie Wydawnictwo Oświatowe.

Przyłuska-Fiszer, A., Misiuna, B. (1993). Etyczne aspekty sportu /Ethical aspects of sports/. Warsaw: Wydawnictwo AWF.

Rahner, K. (1979). Bóg stał się czlowiekiem. Medytacje /God become man: meditations/. Poznań: Wydawnictwo Diecezjalne.

Sahaj, T. (2007). Fani futbolowi. Historyczno-społeczne studium zjawiska kibicowania /Football fans: social-historical study of the phenomenon of rooting/. Poznań: Wydawnictwo AWF. 
Salamon-Krakowska, K. (2007). Malowanie słowami: rzecz o filozofii Bolesława Micińskiego /Painting with words: on the philosophy of Bolesław Miciński/. Wrocław: Oficyna Wydawnicza ATUT - Wrocławskie Wydawnictwo Oświatowe.

Wohl, A. (1965). Stowo i ruch /The word and the movement/. Warsaw: Wydawnictwo AWF.

Wojtyła, K. (1968). Osoba i czyn /The acting person/. Kraków: Znak.

Zaruski, M. (1958). Na bezdrożach tatrzańskich. Wycieczki, wrażenia i opisy /Tatras off-road: tours, impressions, and descriptions/. Warsaw: Sport i Turystyka.

Zaruski, M. (1958). Z harcerzami na “Zawiszy Czarnym”/The scouts on “Zawisza Czarny”/. Warsaw: Sport i Turystyka.

Zieliński, K. (2004). Teoria wychowania fizycznego w świetle antropologii Karola Wojtyły - Jana Pawła II /The theory of physical education in light of the anthropology of Karol Wojtyła - Pope John Paul II. In Człowiek $i$ wychowanie fizyczne /In Man and physical education/ (pp. 171-232). Warsaw: Wydawnictwo AWF.

AUTHOR'S ADDRESS:

Jerzy Kosiewicz

Department of Philosophy, Chair of the Social Sciences

Josef Pilsudski University of Physical Education in Warsaw

34 Marymoncka str., 00-968 Warsaw, Poland

Email: jerzy.kosiewicz@awf.edu.pl 